March 2000 • NREL/CP-520-28005

\title{
Technologies for the New Millennium: Photovoltaics as a Distributed Resource
}

\author{
Preprint
}

\author{
B. Kroposki and R. DeBlasio
}

To be presented at the IEEE Power Engineering Society (PES) Summer Meeting

Seattle, Washington

July 16-20, 2000

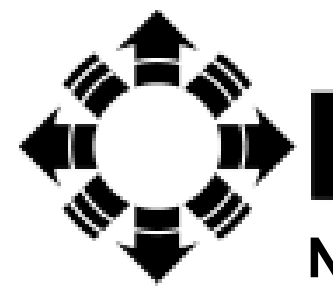

National Renewable Energy Laboratory

1617 Cole Boulevard

Golden, Colorado 80401-3393

NREL is a U.S. Department of Energy Laboratory

Operated by Midwest Research Institute $\bullet$ Battelle $\bullet$ Bechtel

Contract No. DE-AC36-99-G010337 


\section{NOTICE}

The submitted manuscript has been offered by an employee of the Midwest Research Institute (MRI), a contractor of the US Government under Contract No. DE-AC36-99G010337. Accordingly, the US Government and MRI retain a nonexclusive royalty-free license to publish or reproduce the published form of this contribution, or allow others to do so, for US Government purposes.

This report was prepared as an account of work sponsored by an agency of the United States government. Neither the United States government nor any agency thereof, nor any of their employees, makes any warranty, express or implied, or assumes any legal liability or responsibility for the accuracy, completeness, or usefulness of any information, apparatus, product, or process disclosed, or represents that its use would not infringe privately owned rights. Reference herein to any specific commercial product, process, or service by trade name, trademark, manufacturer, or otherwise does not necessarily constitute or imply its endorsement, recommendation, or favoring by the United States government or any agency thereof. The views and opinions of authors expressed herein do not necessarily state or reflect those of the United States government or any agency thereof.

Available electronically at http://www.doe.gov/bridge

Available for a processing fee to U.S. Department of Energy and its contractors, in paper, from:

U.S. Department of Energy

Office of Scientific and Technical Information

P.O. Box 62

Oak Ridge, TN 37831-0062

phone: 865.576 .8401

fax: 865.576.5728

email: reports@adonis.osti.gov

Available for sale to the public, in paper, from:

U.S. Department of Commerce

National Technical Information Service

5285 Port Royal Road

Springfield, VA 22161

phone: 800.553 .6847

fax: 703.605.6900

email: orders@ntis.fedworld.gov

online ordering: http://www.ntis.gov/ordering.htm

Printed on paper containing at least $50 \%$ wastepaper, including $20 \%$ postconsumer waste 


\section{Technologies for the New Millennium: Photovoltaics as a Distributed Resource}

\author{
B. Kroposki, Member, IEEE \\ National Renewable Energy Laboratory \\ 1617 Cole Blvd. \\ Golden, CO 80401
}

\author{
R. DeBlasio, Senior Member, IEEE \\ National Renewable Energy Laboratory \\ 1617 Cole Blvd. \\ Golden, CO 80401
}

\begin{abstract}
As we enter the new millennium, photovoltaics (PV) is emerging as an important distributed resource. PV gives both the benefits of a distributed resource and a clean power source. Because PV can be located at both residential and commercial locations, it can be used to reduce peak demand when its output is properly matched with load usage. It can also improve asset utilization by requiring less large capital generation spending and delaying some equipment replacement. With the price of some grid-connected PV systems expected to reach $\$ 3 / \mathrm{W}$ in the next 5 years, PV will become an economical option for distributed power generation. One of the most important aspects of establishing PV as a distributed resource is standardizing the requirements for grid connection. IEEE Standards Coordinating Committee (SCC) 21 has recently published IEEE Std 929 "Recommend Practice for Utility Interface of Photovoltaic Systems." This recommended practice details power quality, safety, and protection requirements for connection to the utility grid. This paper describes what types of PV systems are available, what the benefits are for PV systems, and what the interconnection issues and solutions are for using PV as a distributed resource.
\end{abstract}

Keywords: Photovoltaics, Distributed Resource, Standards, Utility Interconnection, Grid-Connected, Distributed Generation

\section{INTRODUCTION}

Deregulation of the electric utility industry is providing an opportunity for higher penetration and use of distributed resources (DR). Distributed resources are generation sources that can be located at or near loads. Distributed resources can provide benefits that bulk power generation can not. PV systems are ideally suited for distributed resource applications. Photovoltaic (PV) systems produce DC electricity when sunlight shines on the PV array, without any emissions. The DC power is converted to AC power with an inverter and can be used to power local loads or fed back to the utility. The fuel source for photovoltaic systems -sunlight- is naturally distributed. Distributed PV systems can be mounted on currently "free" real estate, such as building roofs. PV systems are extremely modular and can be sized from 100 watts to several megawatts. Although PV systems can only produce electricity during the day, they can be matched with energy storage devices such as batteries to make a system that can meet the load continuously.

\section{TYPES OF PHOTOVOLTAIC SYSTEMS}

\section{A. Grid-Connected PV Systems}

Grid-connected PV systems consist of a PV array and an inverter connected to an electrical utility power grid. When sunlight strikes the PV array, it generates DC electricity. The electricity is then fed to an inverter, which converts the electricity into AC power that matches the voltage and frequency of the electrical utility. All of the power produced by the system is fed to the utility at the point of common coupling. For residential systems, this occurs at the point at which the electric utility and the customer interface. Onsite loads use the power that is generated by the PV system during the day. Any excess power is fed back to the utility. During the night and periods of shortfall, the electricity comes from the utility to power the loads. All gridconnected PV systems can act as distributed resources.

Grid-connected PV systems range from 100 watts to several megawatts. In the smaller power range, one option are $\mathrm{AC}$ modules, which are complete systems with a module and inverter in one package. AC module power can range between 100-300 watts. There are several benefits of AC modules. They allow users to install small PV systems that are easily expandable. They also add a level of redundancy in the case of inverter failure for systems that have more than one $\mathrm{AC}$ module.

Most residential PV systems range from 1-5 kW, depending on available area. PV systems in this size range usually consist of a PV array (20-100 modules) connected to one inverter properly sized to the array. Most of these systems are located on the roofs of residential homes.

Systems that range in power levels from $10-100 \mathrm{~kW}$ are typically customer-sited. Systems of this size are increasingly becoming cost competitive with traditional power sources $[1,2]$.

Grid-connected PV systems larger than $100 \mathrm{~kW}$ are typically utility-owned and are used as distributed resources, as well as bulk power generation. Examples 
of systems this size used as distributed resources are systems placed at the end of feeder lines to improve voltage sags near customer loads.

\section{B. Stand-Alone PV Systems}

Stand-alone PV systems consist of a PV array, energy storage device (e.g. batteries), loads, and possibly an inverter, depending on load requirements. These systems are designed for specific applications and are not usually considered when designing utility distributed resource applications. The benefit of this type of system is that they are usually cost-effective solutions for a particular problem (e.g. light in remote locations where no utility is present). Because of the economic benefits, most PV systems are of this type.

\section{Hybrid PV Systems}

Hybrid PV systems contain at least one other generation source (e.g. wind turbine, generator) that is not a utility. These types of systems are used where there is a need for continuous power and the PV array cannot always produce enough power to cover the load.

\section{BENEFITS OF PHOTOVOLTAICS}

Using PV as a distributed resource has several benefits. Because PV can be located at both residential and commercial locations, it can be used to reduce peak demand when its output is properly matched with load usage. PV can shave peak demands on the utility grid. Demand for electricity often is highest just when the sun is at its brightest, during the hottest parts of the hottest days.

The use of PV systems can also improve asset utilization by reducing required capital generation spending and delaying some equipment replacement. It can also lessen the need for new central generation equipment and new transmission and distribution lines $[3,4]$.

PV is also a clean, renewable resource. The fuel supply for PV systems although variable is also free and unending. PV systems create no emissions when producing power. Avoided emissions is a very positive aspect of PV power. A $10 \mathrm{~kW}$ PV system in Colorado avoids 22,456 lbs. in $\mathrm{CO}_{2}$ emissions and $4 \mathrm{lbs}$. in $\mathrm{NO}_{\mathrm{x}}$ emissions [5].

Currently, the lowest documented price for grid-tied PV systems in the United States as of 1998 , was $\$ 5.07 / \mathrm{W}$ [6]. With the price of grid-connected PV systems expected to reach $\$ 3 / \mathrm{W}$ in the next 5 years [7], PV will become an economical option for distributed power generation.

\section{PERFORMANCE AND RELIABILITY}

Terrestrial PV systems have been in use for over 20 years [8]. During this time, there have been marked improvements in the performance and reliability of the PV systems and their components.

Improvements have been made in the quality and reliability of PV modules due, in part, to the development of module qualification and safety testing. IEEE 1262 "Recommended Practice for Qualification of PV Modules" [9] and UL 1703 "Flat-Plate Photovoltaic Modules and Panels" [10] provide test procedures to evaluate module design performance, safety, and susceptibility to known failure mechanisms. In these tests, emphasis is placed on testing the module for known degradation mechanisms resulting from environmental weathering, mechanical loading, corrosion, and shadowing. Some PV manufacturers are currently offering up to 25 -year warranties on their products.

PV system inverters have also improved in their reliability. Inverter reliability was a significant issue with early system installation projects conducted by the Sacramento Municipal Utility District (SMUD) and the U.S. Environmental Protection Agency (EPA) [11]. Data from new installations show that inverter reliability is improving through concerted efforts by the inverter manufacturers to improve their quality control and inhouse testing [12].

System maintenance issues fall into the area of system reliability. Properly designed and installed PV systems usually require little maintenance, unless a component fails. Maintenance for stand-alone and hybrid systems is usually considerably greater than for grid-connected systems because of the use of batteries or other generation sources.

\section{INTERCONNECTION ISSUES}

One of the most important aspects of establishing PV as a distributed resource is standardizing the requirements for grid connection. There are three important documents that cover the connection of PV systems to the utility grid:

- IEEE 929 "Recommend Practice for Utility Interface of Photovoltaic Systems" [13]

- National Electrical Code (NEC) Article 690 "Solar Photovoltaic Systems" [14]

- UL 1741 "Standard for Static Inverters and Charge Controllers for Use in Photovoltaic Power Systems"[15]. 
IEEE Standards Coordinating Committee (SCC) 21 recently revised and published IEEE 929. This recommended practice details power quality, safety, and protection requirements for connection to the utility grid. The power quality of the PV system interconnected to the utility is defined in the standard by normal operating voltage, frequency, voltage flicker, harmonic distortion, and power factor. Line-commutated PV system inverters are designed to follow and operate at the utility line voltage and frequency. The inverter of the PV system will cease to energize the utility lines whenever the voltage deviates outside of $106 \mathrm{~V}$ to $132 \mathrm{~V}$ on a singlephase $120 \mathrm{~V}$ line. PV systems should have a fixed operating frequency range of 59.3-60.5 Hz. The allowable levels for both voltage flicker and harmonic distortion are described in IEEE 519 [16]. The allowable amounts ensure that there are no adverse effects to other equipment connected to the utility line. Total harmonic current distortion shall be less than $5 \%$ of the fundamental frequency at rated output. Most inverters used in PV systems operate at unity power factor, although 0.85 lagging or leading is allowed in special cases.

IEEE 929 also makes recommendations for ensuring safe operation of the PV system. These recommendations include equipment protective functions and hardware for personnel safety. The following recommendations are for $120 \mathrm{~V}$ base electrical systems with PV systems rated at $10 \mathrm{~kW}$ peak or less. The inverter should sense and respond to voltage and frequency disturbances. Islanding is a condition where a portion of the utility system, which contains both load and generation, is isolated from the remainder of the utility system. Inverters in PV systems are required to have some type of anti-islanding feature that prevents an island condition from occurring. Inverters are also required to remain off-line for five minutes after any out-of-bounds condition. PV systems should not inject DC current greater than $0.5 \%$ of rated inverter output current into the AC utility grid.

Two other requirements for IEEE 929 come from the National Electrical Code. These are grounding and the uses of a utility-interface disconnect switch.

Article 690 "Solar Photovoltaic Systems" of the National Electrical Code covers safe installation practices for PV systems. The NEC covers several areas, including: Circuit Requirements, Disconnecting Means, Wiring Methods, Grounding, Marking, Connection to other Sources, and Storage Batteries. Excellent discussions on the NEC are given in a Sandia Technical Report [17] and are covered in IEEE 1374 "Guide for Terrestrial Photovoltaic Power System Safety" [18].

Two UL documents are relevant to PV systems. UL 1703 "Flat-Plate Photovoltaic Photovoltaic Modules and Panels" covers module safety, and UL 1741 "Standard for Static Inverters and Charge Controllers for Use in Photovoltaic Power Systems" covers the safety of PV inverters and charge controllers. UL 1741 covers the safety of inverters and tests for anti-islanding capabilities and voltage and frequency trip points.

Currently, work is being conducted in IEEE SCC21 to develop an interconnection document for all distributed power resources (e.g. solar, wind, fuel cells, microturbines, and storage). This work is conducted in Project Authorization Request (PAR) 1547 "Standard for Distributed Resources Interconnected with Electric Power Systems" [19]. This document provides a uniform standard for interconnection of distributed resources with electrical power systems. It provides requirements for the performance, operation, testing, safety considerations, and maintenance of the interconnection. This document is scheduled for completion by December 2001.

\section{CONCLUSIONS}

Photovoltaic power shows promise of becoming an effective contributor for distributed resource applications. $\mathrm{PV}$ has a great number of benefits for use as a distributed resource including peak demand shaving and improved asset utilization. PV also provides a clean and renewable energy source. The performance and reliability of PV systems has improved in the last 20 years, with the use of qualification and safety standards. Interconnection requirements and installation codes have been developed for PV systems that will allow for consistent deployment.

\section{ACKNOWLEDGEMENTS}

The authors acknowledge the work of several researchers at the DOE National Laboratories: John Stevens (Sandia National Laboratories) for work in utility interconnection of PV system and chairing the working group for IEEE 929; Ward Bower (Sandia National Laboratories) and John Wiles (Southwest Technology Development Institute) for work on the National Electrical Code and in PV system safety; Christy Herig (National Renewable Energy Laboratory) for promoting the use of photovoltaics in utilities; Tom Basso (National Renewable Energy Laboratory) for facilitating the IEEE SCC21 distributed power interconnection standard development activities as secretary to the IEEE P1547 working group. This work was done under contract DEAC36-99GO10337. 


\section{REFENECES}

[1] Benner, J. and L. Kazmerski, "Photovoltaics Gaining Greater Visibility”, IEEE Spectrum, September 1999, pp. 35-42.

[2] Herig, C., H. Thomas, R. Perez, and H. Wenger, "Residential Customer-Sited Photovoltaics Markets 1999,” ASES 1999 Conference, June 1999.

[3] Hoff, T., H. Wenger, and B. Farmer, "Distributed Generation: An Alternative to Electric Utility Investments in System Capacity," Energy Policy 24(2): 137-147 (1996)

[4] Hoff, T., and D. Shugar, "The Value of Grid-Support Photovoltaics in Reducing Distribution System Losses", IEEE Transactions on Energy Conversion (1995), 10(9):569-576

[5] U.S. Environmental Protection Agency, Global Warming Web Site, Annual Emissions Calculator, http://199.223.18.230/epa/rew/rew.nsf/solar/index.html February 1999.

[6] Osborn, D., "Commercialization and business Development of Grid-Connected Photovoltaics at SMUD”, Solar 98: Renewable Energy for the Americas Conference, Albuquerque, June 1998.

[7] Thomas, H., B. Kroposki, P. McNutt, C. Witt, W. Bower, R. Bonn, and T. Hund, "Progress in Photovoltaic System and Component Improvements," $2^{\text {nd }}$ World Conference and Exhibition on Photovoltaic Solar Energy Conversion, Vienna, 1998, pp. 1930-1935.

[8] Thomas, M., H. Post, and R. DeBlasio, "Photovoltaic Systems: An End-of-Millennium Review", Progress in Photovoltaics: Research and Applications 7, 1-19, 1999.

[9] IEEE Std. 1262 "Recommended Practice for Qualification of Photovoltaic Modules."

[10] UL Subject 1703, "Flat-Plate Photovoltaic Modules and Panels."

[11] Maish, C. Atcitty, S. Hester, D. Greenberg, D. Osborn, D. Collier, and M. Brine, "Photovoltaic System Reliability," $26^{\text {th }}$ IEEE PV Specialist Conference, Anaheim, September 1997.

[12] Stefanac, D. "Process Quality in Manufacturing PV Power Conversion Products," 1998 PV Performance and Reliability Workshop, Cocoa Beach, Florida, November 1998.

[13] IEEE Std 929 "Recommended Practice for Utility Interface of Photovoltaic Systems."
[14] NFPA 70-1999, National Electrical Code (NEC).

[15] UL Subject 1741, "Standard for Static Inverters and Charge Controllers for Use in Photovoltaic Power Systems."

[16] IEEE Std 519-1992 "Recommended Practices and Requirements for Harmonic Control in Electrical Power Systems."

[17] Wiles, J. Sandia Report SAND96-2797, "Photovoltaic Power Systems and The National Electrical Code : Suggested Practices," 1996.

[18] IEEE Std 1374 "Guide for terrestrial Photovoltaic Power System Safety."

[19] IEEE Project 1547 "Standard for Distributed Resources Interconnected with Electric Power Systems." http://grouper.ieee.org/groups/scc21/1547 March 2000.

\section{BIOGRAPHIES}

Benjamin Kroposki (S-90, M-93) is a senior engineer in the National Center for Photovoltaics at the National Renewable Energy Laboratory (NREL) and Team Leader for the Engineering and Technology Validation Team. His expertise is in design and testing of photovoltaic systems, and he has over 25 publications in the area of photovoltaics. Mr. Kroposki also participates in the development of photovoltaic standards and codes, including IEEE, IEC, and NEC. Mr. Kroposki received his Bachelor and Masters degree in Electrical Engineering from Virginia Tech and is a registered Professional Engineer.

Richard DeBlasio (M-65, SM-83) is a Principal Engineer and leads the Distributed Power Program and Photovoltaic System Performance and Standards Development activities at the U. S. National Renewable Energy Laboratory (NREL). Before joining NREL (SERI) in 1978, he was with the U.S. Atomic Energy Commission in Washington, D.C., Underwriters Laboratories, and Stanford University. Mr. DeBlasio has focused primarily on system and component energy conversion and performance, design verification, reliability research, safety evaluation, and standards development and has over 30 publications in the area of photovoltaics. He is an electrical engineer, a senior member of the IEEE, chairs the IEEE Standards Board Coordinating Committee 21 on Fuel Cells, Photovoltaics, Distributed Power, and Energy Storage, chairs the International Electrotechnical Commission Technical Committee 82 on Photovoltaic Systems, and serves on the Board of Directors of the Global Approval Program and the PowerMark Corporation for component and system testing and certification, and laboratory accreditation. 


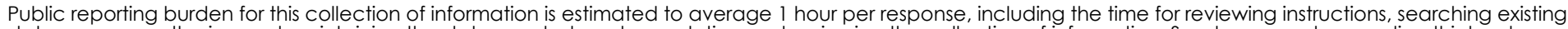

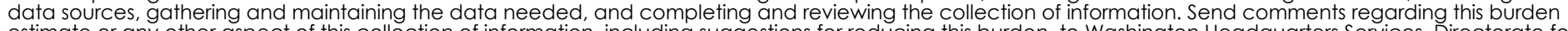

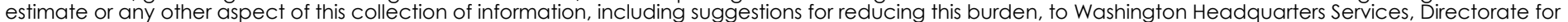

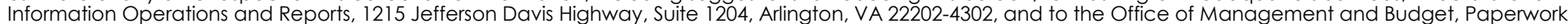
Reduction Project (0704-0188), Washington, DC 20503.

\begin{tabular}{|l|l|l|l}
\hline 1. AGENCY USE ONLY (Leave blank) & $\begin{array}{l}\text { 2. REPORT DATE } \\
\text { March } 2000\end{array}$ & $\begin{array}{l}\text { 3. REPORT TYPE AND DATES COVERED } \\
\text { conference paper }\end{array}$ \\
\hline
\end{tabular}

4. TITLE AND SUBTITLE
Technologies for the New Millennium: Photovoltaics as a Distributed Resource

6. AUTHOR(S)

B. Kroposki and R. DeBlasio

7. PERFORMING ORGANIZATION NAME(S) AND ADDRESS(ES)

TA: PV007301

8. PERFORMING ORGANIZATION REPORT NUMBER

9. SPONSORING/MONITORING AGENCY NAME(S) AND ADDRESS(ES)

National Renewable Energy Laboratory

10. SPONSORING/MONITORING

1617 Cole Blvd.

Golden, CO 80401-3393

AGENCY REPORT NUMBER

11. SUPPLEMENTARY NOTES

12a. DISTRIBUTION/AVAILABILITY STATEMENT

National Technical Information Service

12b. DISTRIBUTION CODE

U.S. Department of Commerce

5285 Port Royal Road

Springfield, VA 22161

13. ABSTRACT (Maximum 200 words)

As we enter the new millennium, photovoltaics (PV) is emerging as an important distributed resource. PV gives both the benefits of a distributed resource and a clean power source. Because PV can be located at both residential and commercial locations, it can be used to reduce peak demand when its output is properly matched with load usage. It can also improve asset utilization by requiring less large capital generation spending and delaying some equipment replacement. With the price of some grid-connected PV systems expected to reach $\$ 3 / \mathrm{W}$ in the next 5 years, PV will become an economical option for distributed power generation. One of the most important aspects of establishing PV as a distributed resource is standardizing the requirements for grid connection. IEEE Standards Coordinating Committee (SCC) 21 has recently published IEEE Std 929 "Recommend Practice for Utility Interface of Photovoltaic Systems." This recommended practice details power quality, safety, and protection requirements for connection to the utility grid. This paper describes what types of PV systems are available, what the benefits are for PV systems, and what the interconnection issues and solutions are for using PV as a distributed resource.

\begin{tabular}{|c|c|c|c|}
\hline \multirow{2}{*}{\multicolumn{3}{|c|}{$\begin{array}{l}\text { 14. SUBJECT TERMS } \\
\text { photovoltaics ; distributed resource ; standards ; utility interconnection ; grid-connected ; } \\
\text { distributed generation }\end{array}$}} & \multirow{2}{*}{$\begin{array}{l}\text { 15. NUMBER OF PAGES } \\
\text { 16. PRICE CODE }\end{array}$} \\
\hline & & & \\
\hline $\begin{array}{l}\text { 17. SECURITY CLASSIFICATION } \\
\text { OF REPORT } \\
\text { Unclassified }\end{array}$ & $\begin{array}{l}\text { 18. SECURITY } \\
\text { CLASSIFICATION } \\
\text { OF THIS PAGE } \\
\text { Unclassified }\end{array}$ & $\begin{array}{l}\text { 19. SECURITY CLASSIFICATION } \\
\text { OF ABSTRACT } \\
\text { Unclassified }\end{array}$ & $\begin{array}{l}\text { 20. LIMITATION OF ABSTRACT } \\
\text { UL }\end{array}$ \\
\hline
\end{tabular}

